MAREK FILIPCZUK, WARSZAWA

\title{
WYCHOWAWCZA FUNKCJA KOŚCIOKA W DOBIE PONOWOCZESNOŚCI
}

W kształtowaniu prawego sumienia, a tym samym całej struktury moralnej osoby ludzkiej, nie można przeoczyć roli Kościoła, jako nauczyciela wyzwalającej prawdy o człowieku. Wychowawcza funkcja tej wspólnoty aktualizuje się przez działalność nauczycielską, liturgiczna i pastoralną. Są to podstawowe funkcje urzeczywistniania się Kościoła. ${ }^{1} \mathrm{~W}$ encyklice Humanae vitae Kościół zostaje nazwany Matką i Nauczycielką wszystkich ludów. ${ }^{2}$ Dlatego „troszczy się [on] o dowartościowanie sumienia, ponieważ zarówno w porządku moralnym, jaki i na płaszczyźnie ściśle religijnej uważa się za Bożego rzecznika, który działa dla dobra ludzi, a więc oświeca sumienia, kształtuje je i im służy". ${ }^{3}$ Konieczne jest, aby był on wychowawcą na wszystkich płaszczyznach swojego życia i działania, by w ten sposób przyczyniać się do kształtowania katalogu podstawowych wartości. ${ }^{4}$ Człowiek dojrzały będzie postrzegał Magisterium jako swego sojusznika, który pomaga mu szybciej, pewniej i dokładniej

1 Por. B. D r o ż d ż, Wychowawcza funkcja Kościoła w społeczeństwie pluralistycznym. Studium pastoralne, Legnica 1997, s. 173.

2 HV nr 19.

3 J a n P a w e $\nmid$ II, „Tak” dla Kościoła. Katechezy o Kościele, Kraków-Ząbki 1999, $\mathrm{nr} 4$.

4 Por. K. Pó 1 t o r a k, Pedagogika pastoralna. Nowe inspiracje duszpasterskie, Teologia praktyczna t. 2/ 2001, s. 73; J. K r u c i n a, Komentarz do encykliki Jana Pawła II „Centesimus annus”, w: J a n P a w e 1 II, Centesimus annus, Wrocław 2000, s. 141. W encyklice Veritatis splendor pada wręcz sformułowanie: „W kształtowaniu sumienia bardzo pomaga chrześcijanom Kościół i jego «Magisterium»"; VS nr 64 . 
poznać prawdę. W takiej perspektywie Kościół powinien być postrzegany jako właściwy pośrednik w dialogu sumienia z Chrystusem. ${ }^{5}$

\section{Prawo do prawdy - fundamentalna opcja Kościoła}

W społeczeństwie pluralistycznym, absolutyzującym rozum, pracę i sukces, w którym ludzie przyzwyczajeni są do panowania nad materią i przekształcania jej według własnej woli, powstaje niebezpieczeństwo manipulowania sumieniem. ${ }^{6}$ Dzieje się tak, ponieważ jedną z pokus powracających we wszystkich czasach również wśród chrześcijan jest uważanie siebie za depozytariuszy prawdy, zapominając przy tym, że interpretowanie słowa Pisma, jak i ogólnie rzecz biorąc objawienia, nie jest sprawą prywatną, tj. sprawą pojedynczej osoby jako jednostki. ${ }^{7}$ Dzieje się to często także na skutek utartego powszechnie dziś przesądu jakoby najpewniejszym kryterium mojej wolności i samodzielności w poszukiwaniu prawdy było to, że potrafiłem odstąpić od przeświadczeń wyznawanych przez większość. Dlatego w imię rzeczywistej wolności sumienia Kościół broni prawa do prawdy i pragnie - na wzór swego Mistrza Jezusa Chrystusa samym sposobem odnoszenia się do człowieka podkreślać i potwierdzać jego suwerenną podmiotowość. ${ }^{8}$

Każde sumienie, ożywione szczerą miłością prawdy, z pewnością odczuwa pragnienie poznania, a zatem przynajmniej wysłuchania

5 Por. A. L a u n, Sumienie contra Magisterium? Ethos 3-4/1991, s. 224; A. Fro s s a rd, ,Nie lękajcie się”. Rozmowy z Janem Pawłem II, Watykan 1982, s. 132.

6 Por. R. K a m iń s k i, Duszpasterstwo w społeczeństwie pluralistycznym, Lublin 1997, s. 25.

7 Por. R. G u a r d in i, Pismo Święte i nauka wiary. Poznanie duchowe, które otrzymuje się w darze, Kielce 2002, s. 61.

8 Por. J. S a 1 i j, Po co nam Kościół? Poznań-Kraków 2001, s. 23; A. S z o s te k, Rola Kościoła w kształtowaniu dojrzałego sumienia, W drodze 2/1984, s. 55. W deklaracji Dominus Iesus czytamy: „Kościół (...), powodowany miłością i poszanowaniem wolności, musi troszczyć się przede wszystkim o przepowiadanie wszystkim ludziom prawdy, objawionej w sposób definitywny przez Pana"; DI nr 22. 
tego, co Ewangelia głoszona przez Kościół mówi człowiekowi dla jego dobra. W niej człowiek znajduje nie tylko cały zespół norm, zasad postępowania, przykazań, ale także zaleceń i rad zaadresowanych do sumienia, czyli do człowieka wewnętrznego. ${ }^{9}$ Zasady prawa naturalnego dostarczają, szczególnie w chaosie politycznym, nie tylko właściwej orientacji (służą za busolę życia społeczno-państwowego), ale i zakotwiczenia w Bogu, który jest dla nich ostatecznym źródłem mocy wiążącej. ${ }^{10} \mathrm{~W}$ soborowej deklaracji o wolności religijnej czytamy: „Chrześcijanie (...) w kształtowaniu swego sumienia powinni pilnie baczyć na świętą i pewną naukę Kościoła. Z woli bowiem Chrystusa Kościół katolicki jest nauczycielem prawdy i ciąży na nim obowiązek, aby głosił i autentycznie nauczał Prawdy, którą jest Chrystus, a zarazem powagą swoją wyjaśniał i potwierdzał zasady porządku moralnego, wynikające z samej natury ludzkiej”. ${ }^{11}$ Uczenie moralności zatem to przede wszystkim sprawa kształtowania wnętrza: oświecanie sumienia światłem prawdy i umacnianie woli do wybierania dobra, utwierdzanie w dobrym i spełnianie dobrych czynów. ${ }^{12}$

Kościół, który w czasach nazistowskiego i komunistycznego zniewolenia odegrał ważną rolę jako obrońca praw sumienia, również dzisiaj powinien wskazywać na ewangeliczną prawdę o godności każdego człowieka. Jego zadaniem jest bowiem ułatwianie umysłom i sumieniom dostępu do prawdy Bożej objawionej w Chrystusie, który powierzył apostołom i Kościołowi tę posługę - diakonię prawdy w miłości. ${ }^{13}$ Mater Ecclesia nade wszystko chroni swe dzieci przed niebezpieczeństwami zagrażającymi ich życiu, zdrowiu i szczęściu; taka ochrona bowiem jest naturalną kontynuacją jej zaszczytnego

9 Por. J a n P a weł II, „Tak” dla Kościoła, nr 4; A. F ro s s a r d, ,Nie lękajcie się". Rozmowy z Janem Pawtem II, s. 132.

10 Por. J. K r u c i n a, Sumienie społeczeństwa, Wrocław 1995, s. 201.

11 DWR nr 14.

12 Por. A. F r o s s a r d, ,, Nie lękajcie się”. Rozmowy z Janem Pawłem II, s. 132.

13 Por. J a n P a we 1 II, ,,Tak” dla Kościoła, nr 4. 
miana i roli Rodzicielki. Kościół zatem wymaga tego, czego domaga się godność osoby i podstawowy ład społeczny. ${ }^{14}$

Po ideologii, która się kompletnie skompromitowała, została wielka pustka. Okazało się, że Kościół głosił przez cały czas „,wielką rację". Kościół, będąc nieprzerwanie sługą człowieka, myśli o tym, co można ocalić i zabezpieczyć dla prawdziwego dobra osoby ludzkiej z tych dróg, na które wprowadziły go współczesne ideologie, ustroje i systemy. ${ }^{15}$ Kościół, nazywany znawcą spraw ludzkich, widząc zagrożenie i wewnętrzną walkę, będącą udziałem człowieka żyjącego w społeczeństwie pluralistycznym, przez swoją obecność i duszpasterstwo roztacza troskę, w świetle której egzystencja człowieka nabiera nowego blasku i nadziei. ${ }^{16}$ „Kościół nie zaprzestaje swej modlitwy i posługi, ażeby dzieje sumień i dzieje społeczeństw w wielkiej rodzinie ludzkiej «nie opadały w stronę bieguna grzechu», w stronę odrzucenia Bożych przykazań «aż do pogardy Boga» - ale «wznosiły się w stronę tej miłości», w której objawia się Duch, który daje życie". ${ }^{17}$

„Formacja prawego sumienie wiernych, poczynając od dzieci i młodzieży, musi być stałą troską Kościoła, nade wszystko dlatego, że ma on za zadanie wskazywania wszystkim ludziom drogi zbawienia, a wierzącym udzielania życia Chrystusowego i wspomagania ich ustawiczną opieką, aby mogli osiągnąć pełnię tego życia". ${ }^{18} \mathrm{Jemu}$ bowiem zostało powierzone prawo Boże objawione przez Chrystusa i stanowiące normę dla ludzkiego sumienia. Jest ono autentycznym słowem Bożym i rzeczywiście może nas napełnić światłem i mocą,

14 Por. A. S z o s t e k, Rola Kościoła w kształtowaniu dojrzałego sumienia, s. 55; A. F r o s s a r d, ,Nie lękajcie się”. Rozmowy z Janem Pawłem II, s. 135.

15 Por. tamże, s. 250-251.

16 Por. R. K a m iń s k i, Duszpasterstwo w społeczeństwie pluralistycznym, s. 26

17 DV nr 48.

$18 \mathrm{~J}$ a n P aw e $\nmid$ II, Odnowa człowieka i społeczeństwa dokonuje się za sprawa odnowy sumień. Przemówienie do biskupów polskich z 14 II 1998 r., w: M. C z e k a ń s k i (red.), Sumienie. Głos Boga w duszy. Wybór tekstów, Kraków 2002, s. 131; zob. także: DWCh nr 3. 
które od samego Boga pochodzą. Sumienie i prawo moralne mają zatem to samo źródło - pochodzą od Boga.$^{19}$ Naturalną konsekwencją tego faktu jest prawda, że Kościół w sprawach wiary i moralności pełni rolę prawdziwego nauczyciela i przewodnika, gdyż czuje się odpowiedzialny za sumienia wszystkich wiernych. Wie bowiem, że tam, gdzie moralność traci znaczenie, traci przede wszystkim sam człowiek, tracą najpierw najsłabsi, ponieważ moralność jest sprawą sumienia i decyzji, sprawą wnętrza ludzkiego. ${ }^{20}$

\section{Kościół jako Matka i jako Nauczycielka}

Kościół dwojako przyczynia się do kształtowania dojrzałego sumienia w człowieku: jako Matka i jako Nauczycielka. Należy jednak od razu dodać, że Ecclesia jest najpierw Mater, która rodzi i wychowuje dzieci, potem dopiero Magistra. Ponieważ sumienie w swej istocie jest rzeczywistością religijną, dlatego właściwym miejscem formacji sumienia jest Kościół; w nim sumienie wzrasta i dojrzewa, a posługa ta poparta jest autorytetem samego Jezusa Chrystusa i asystencją Ducha Świętego. Dlatego ten, kto z jednej strony uznaje obecność Ducha Świętego w Kościele, z drugiej jednak twierdzi, że posłuszny być może jedynie prawdzie własnego sumienia, nie zaś nauce Magisterium, przeczy sam sobie. ${ }^{21}$

Chrystus działa w Kościele i prowadzi Kościół niewidzialną mocą Ducha Świętego i jednocześnie działa w nim mocą słowa i sakramentów. „To Chrystus jest Nauczycielem (...) i pozostaje zawsze obecny w Kościele i w świecie. To On otwiera wiernym księgę Pisma i objawiając w pełni wolę Ojca, naucza prawdy o postępowaniu moralnym". 22 Sumienie chrześcijańskie jest zatem sumieniem

19 Por. J. S a 1 ij, Po co nam Kościót? s. 17.

20 Por. J. R a t z i ng e r, Bóg jest blisko nas. Eucharystia: centrum życia, Kraków 2002, s. 112; A. F r o s s a r d, ,,Nie lękajcie się”. Rozmowy z Janem Pawłem II, s. 131.

${ }^{21}$ Por. A. L a u n, Sumienie contra Magisterium? s. 225.

22 VS nr 8. Por. A. F r o s s a r d, ,Nie lękajcie się”. Rozmowy z Janem Pawtem II, s. 204. 
eklezjalnym: jawi się w osobistej odpowiedzi na wspólne powołanie do wyjścia z siebie, aby otworzyć się na prawdę, która jaśnieje w Chrystusie. ${ }^{23}$ Tak więc „,również człowiek współczesny - jak podkreśla z naciskiem Jan Paweł II - winien zwrócić się na nowo do Chrystusa, aby uzyskać od Niego odpowiedź na pytanie, co jest dobrem, a co złem". ${ }^{24}$ To dlatego właśnie chrześcijanin w realizacji swego życiowego powołania, o którym Kościół stale głosi, że jest doczesne i wieczne zarazem, nie może pominąć Kościoła, ponieważ Bóg przemawia do człowieka w Duchu Świętym przez Kościół. Skoro Kościół jest właściwym miejscem formacji sumienia, zatem każdy człowiek, a szczególnie chrześcijanin, winien je kształtować właśnie w Kościele. ${ }^{25}$ „Droga Kościoła - podkreśla Jan Paweł II - przebiega przez serce człowieka, tam bowiem jest owo ukryte miejsce zbawczego spotkania z Duchem Świętym: z Bogiem ukrytym". ${ }^{26}$

Kościół jako Matka chroni człowieka przed gwałtem naruszającym jego wolność wprost bądź pośrednio. Wprost przez utrudnienie albo uniemożliwienie działania zgodnego z osądem sumienia, pośrednio zaś przez ograniczenie dostępu do prawdy. ${ }^{27}$ Musi on rozbić więzienie pozytywizmu, obudzić wrażliwość człowieka na prawdę, na Boga, a przez to i siłę sumienia. Musi dawać odwagę do życia według sumienia. ${ }^{28}$ Chrześcijanie „,W kształtowaniu swego sumienia powinni pilnie baczyć na świętą i pewną naukę Kościoła", albowiem sąd sumienia zawsze wyrasta z uzasadniających go przesłanek, wśród których nie powinno zabraknąć miejsca dla autorytetu. ${ }^{29}$ Sakramentalna formacja sumienia jest możliwa tylko i wyłącznie w Mistycznym Ciele Chrystusa, tzn. w Kościele świętym. Tu sumienie

23 Por. L. M e 1 i n a, Sumienie-wolność-Magisterium, Ethos 3-4/1991, s. 109.

24 VS nr 8.

25 Por. L. M e 1 i n a, Sumienie - wolność - Magisterium, s. 111.

26 DV nr 67.

27 Por. A. S z o s te k, Rola Kościoła w kształtowaniu dojrzałego sumienia, s. $56-57,64$.

28 J. R a t z i n ge r, Czas przemian w Europie, Kraków 2001, s. 48.

29 DWR nr 14. Por. A. S z o s t e k, Uwagi o formowaniu ,,ludzi sumienia”, Znak 7/1996, s. 71. 
znajduje swoją weryfikację w communio i tak przybiera charakterystyczną konfigurację eklezjalną. Człowiek wierzący bowiem wie, że w zadaniu formowania sumienia pomaga mu w sposób szczególny nauka Kościoła. A Kościół przychodzi do współczesnego człowieka żyjącego w pluralistycznym społeczeństwie z nauką ewangeliczną i z faktem odkupienia, które dokonało się przed wiekami, ale trwa do dnia dzisiejszego i obejmuje swym skutkiem każdego człowieka. ${ }^{30}$

Zadaniem Kościoła jest przede wszystkim wychowywanie. Kościół pragnie nade wszystko wychowywać przez rodzinę, opierając się na właściwej jej łasce stanu i charyzmacie wspólnoty rodzinnej. ${ }^{31} \mathrm{~W}$ tym zadaniu szczególnie przejawia się rola Kościoła jako Matki, która rodzi i wychowuje dzieci. Kościół „nie może odstąpić człowieka”, ponieważ człowiek jest ,pierwszą i podstawową drogą Kościoła". ${ }^{32}$ Kościół zatem oddziałuje wychowawczo za pomocą takich środków, jak: nauczanie moralne, sakramenty, liturgia oraz ćwiczenia i przewodnictwo duchowe, ale także przez różnorodne inicjatywy i przedsięwzięcia, ruchy i organizacje młodzieżowe. ${ }^{33}$

\section{Wychowanie do dojrzałej miłości - podstawowym celem pedagogii Kościoła}

Jako Nauczycielka Kościół nade wszystko pragnie nauczyć człowieka miłości, prowadząc go w tym celu wielorako do swego Oblubieńca, Miłości wcielonej, której prawdziwa istota stała się widzialna w Jezusie Chrystusie, zarówno w Jego słowie, jak i w życiu i śmierci. ${ }^{34}$ W ten sposób Chrystus jest wciąż w nim obecny i wciąż niesłychanie

${ }^{30}$ Por. R. K a m iń s k i, Duszpasterstwo w społeczeństwie pluralistycznym, s. 37.

31 Por. J. R a t z i n g e r, Czas przemian w Europie, s. 48; J a n P a w e 1 II, List do rodzin, nr 16.

$32 \mathrm{RH}$ nr 14.

33 Por. J. Mar it a i n, Moralne i duchowe wartości w wychowaniu, w: F. A d a m s k i (red.), Człowiek - wychowanie - kultura, Kraków 1993, s. 140.

${ }^{34}$ Por. A. S z o s te k, Rola Kościoła w kształtowaniu dojrzałego sumienia, s. 64. 
czynny mocą krzyża i tajemnicy paschalnej, a Kościół, dzięki tej stale działającej mocy swego Pana i Oblubieńca, staje się prawdziwie Jego Ciałem Mistycznym. ${ }^{35}$ Trzeba zatem koniecznie bytować w Mistycznym Ciele Chrystusa i Nim żyć, ponieważ relacja osoby ludzkiej do Chrystusa to conditio sine qua non sakramentalnej formacji sumienia. Ta miłość oznacza, że Bóg przyjmuje nas bez warunków wstępnych, nawet, gdy nie jesteśmy jej godni czy zdolni przyjąć, ponieważ On, Jezus Chrystus, przemienia nas i staje się naszym Bratem. ${ }^{36}$ Tylko przyzwyczajenie do tego, co boskie, czyni nas nieraz niewrażliwymi na tę lawinę łask i świateł, jaką Kościół nieustannie na nas zlewa, a której chętnie pozwalamy spadać w próżnię. ${ }^{37}$

W tej sytuacji należy zdać sobie sprawę z tego, że niebezpieczne jest przebywanie w stałej bliskości sacrum. Może ono wówczas stać się dla człowieka czymś powszednim i zwyczajnym, a przez to nawet jego zgubą. Tak więc wysiłek pracy moralnej, środkami której Kościół stara się wychować człowieka, koncentruje się na rozwoju, wzmacnianiu i zachowaniu w czystości miłości, która sprawia, że nie możemy być bliźnimi kogoś, komu opatrujemy rany i czujemy jedynie współczucie. ${ }^{38}$ Miłość ta bowiem stanowi o „być albo nie być” ludzkiej osoby, gdyż kształtuje ona istotę chrześcijańskiej egzystencji. Miłość ludzka, podobnie jak miłość Boga, nie jest kwestią treningu, ponieważ jest darem. Miłość Boga może być naczelną zasadą postępowania, gdyż jest darem natury i łaski. To właśnie sprawia, że przykazanie miłości nie czyni chrześcijaństwa religią prawa. ${ }^{39}$

Kościół uczy człowieka miłości. Można nawet powiedzieć, że miłość jest jedynym podmiotem, który Kościół chce człowiekowi

35 Por. A. F ro s s a r d, „, Nie lękajcie się”. Rozmowy z Janem Pawłem II, s. 203.

36 Por. J. R a t z i n g e r, Bóg jest blisko nas. Eucharystia: centrum życia, s. 32; A. J. N o w a k, Psychogeneza sumienia, Roczniki Teologiczne 41(1994) z. 5, s. 99.

37 Por. A. F r o s s a r d, ,Nie lękajcie się”. Rozmowy z Janem Pawłem II, s. 201.

38 Por. J. R a t z i n g e r, Nowa pieśń dla Pana. Wiara w Chrystusa a liturgia dzisiaj, Kraków 2005, s. 269; J. M a r i t a i n, Moralne i duchowe wartości w wychowaniu, s. 140.

39 Por. tamże, s. 139; A. H o fe r, Formuly wiary dla wierzacych? Ateneum Kapłańskie 124(1995) z. 1, s. 89. 
wyłożyć, jedyną sztuką, w jakiej chce go uczynić sprawnym, nie znamy bowiem lepszego sposobu komunikacji niż miłość. ${ }^{40}$ Miłość zaś można zrozumieć tylko w niej uczestnicząc, albowiem staranne poznanie jest wewnętrznym postulatem miłości. ${ }^{41}$ Wolność sumienia jest wolnością, która rodzi się z miłości i jest na nią ukierunkowana. Chrystus jest najbardziej wolny właśnie w momencie najwyższego podporządkowania się i posłuszeństwa wymogom zbawczej Miłości Ojca - w momencie swojej śmierci, albowiem prawdziwa wolność to ta, która poddaje się wymogom miłości. Możemy się o tym przekonać: im głębiej zejdziemy w ciemność niezrozumienia, pokładając w Nim ufność, tym bardziej Go odnajdziemy; odnajdziemy miłość i wolność, która przeniesie nas przez wszystkie ciemności. ${ }^{42}$ Dlatego ostateczne znaczenie każdej normy moralnej leży w miłości. „Chrystus ukrzyżowany objawia autentyczny sens wolności, w pełni go realizuje przez całkowity dar z siebie i powołuje swoich uczniów do udziału w tej samej wolności”. ${ }^{43}$ Niosąc pomoc sumieniu, Kościół nie zamierza w żadnym razie wyręczać go, a tym bardziej łamać jego wolności. Przeciwnie, z wypowiedzi II Soboru Watykańskiego jasno wynika, że Kościół uznaje niezastąpioną wartość sumienia i broni jego prawa, odnosząc to wyraźnie do dziedziny religijnej. ${ }^{44}$ Posłuszeństwo sumieniu sprawia, że „służyć Chrystusowi” znaczy właściwie ,panować”, ponieważ posłuszeństwo sumieniu jest udziałem w „królewskim Urzędzie Chrystusa” ${ }^{45}$

40 Por. A. S z o s t e k, Rola Kościoła w kształtowaniu dojrzałego sumienia, s. 60; A. F r o s s a r d, „Nie lękajcie się”. Rozmowy z Janem Pawłem II, s. 203.

${ }_{41}$ Por. J. R a t z i n g e r, Bóg jest blisko nas. Eucharystia: centrum życia, Kraków 2002, s. 113; t e n ż e, Nowa pieśń dla Pana, s. 266.

${ }_{42}$ Por. J. R a t z i ng e r, Bóg jest blisko nas. Eucharystia: centrum życia, s. 51.

$43 \mathrm{VS}$ nr 85.

44 Por. S. O l e j n i k, Teologia moralna fundamentalna, Włocławek 1998, s. 248.

45 Por. J. R a t z i n g e r, Bógjest blisko nas. Eucharystia: centrum życia, s. 121. Kto domaga się prawa do postępowania według własnego sumienia, a nie uznaje jednocześnie obowiązku podporządkowania go prawdzie i prawu wpisanemu w nasze serca przez samego Boga, w rzeczywistości przypisuje nadrzędną wartość swojemu ograniczonemu sądowi. 
W kompetencjach Nauczycielskiego Urzędu Kościoła leży zatem interpretowanie naturalnego prawa moralnego. ${ }^{46} \mathrm{Ta}$ wierność wobec Urzędu Nauczycielskiego Kościoła nie pozwala sumieniu zboczyć z drogi prawdy odnoszącej się do dobra człowieka, gdyż „w posłuszeństwie człowieka wobec własnego sumienia leżą klucze do moralnej wielkości człowieka i istotna podstawa jego «królewskiej godności $» "{ }^{47}$ Człowiek dojrzale posłuszny nie czuje się więc zagrożony w swojej autonomii przez autorytet nauczającego Kościoła. ${ }^{48}$

\section{Sumienie osoby a Urząd Nauczycielski Kościoła}

Funkcjonowanie obok siebie modelu moralności opartej na sumieniu i moralności opartej na autorytecie może się niekiedy wydawać koncepcją przeciwstawną. Tymczasem nie jest słuszne uważać sumienie jednostki i Urzędu Nauczycielskiego Kościoła za rzeczywistości zwalczające się, będące w konflikcie. ${ }^{49}$,Jezus Chrystus, czyniąc Piotra i Apostołów uczestnikami swojej boskiej władzy i posyłając ich, aby nauczali wszystkie narody Jego przykazań, ustanowił ich zarazem autentycznymi strażnikami i tłumaczami całego prawa moralnego, a więc nie tylko ewangelicznego, ale także naturalnego". ${ }^{50}$ Prawo Boże zostało zatem powierzone Kościołowi, aby przez niego było strzeżone, autentycznie wyjaśniane i głoszone ludziom, dlatego też Kościół ma kompetencje w zakresie przekazywania wiedzy moralnej i kształtowania sumień w świetle prawa Bożego. Autorytet, którym z woli Chrystusa cieszy się Kościół, istnieje po to, by sumienie

46 HV nr 4.

47 Por. J a n $\mathrm{P}$ a w e 1 II, Kościól jest miejscem, w którym sumienie ludzkie wzrasta i dojrzewa, nr 3. Zob. także: J. R a t z i n g e r, Bóg jest blisko nas. Eucharystia: centrum życia, s. 121.

48 Por. A. L a u n, Sumienie contra Magisterium? s. 224.

49 Por. J. R a t z i n g e r, Prawda, wartości, władza, Kraków 1998, s. 25; S. O l e j$\mathrm{n}$ i k, Teologia moralna fundamentalna, s. 248.

$50 \mathrm{HV}$ nr 4. 
bezpiecznie osiągnęło prawdę i w niej trwało. ${ }^{51}$ Człowiek bowiem ginie, dziś o tym wiemy, gdy sam wciąż musi siebie wymyślać, gdy musi dopiero na nowo stworzyć sobie człowieczeństwo. A więc, gdy autorytet - w tym przypadku Urząd Nauczycielski Kościoła wypowiada się w sprawach moralności, sumienie uzyskuje dzięki tym wypowiedziom materiał do swych sądów, ale musi zachować ostatnie słowo. ${ }^{52}$

Pomoc Kościoła udzielana sumieniu polega na niesieniu mu światła przez głoszenie prawdy i ukazywaniu woli Bożej wyrażonej w Jego Prawie. A wola Boża nie jest dla człowieka jakąś obcą, pochodzącą z zewnątrz siłą, lecz kierunkiem jego istoty. Przedkładane przez Urząd Nauczycielski Kościoła zasady społeczne wywodzą się z transcendencji osoby ludzkiej, z sumienia i intuicji moralnej. Dlatego objawienie woli Bożej jest objawieniem tego, czego pragnie nasza własna istota, czyli łaski. Tak więc w pluralistycznym, ale zmieniającym się świecie, Kościół przychodzi z niezmienną nauką i działaniem łaski Bożej, niezmiennym przykazaniem miłości i powszechnego braterstwa. ${ }^{53}$

Niejednokrotnie ukazywanie relacji sumienie - Magisterium bywa dokonywane w sposób bardzo zewnętrzny, legalistyczny, a zatem minimalistyczny, jak gdyby chodziło o obronę wolności przez sumienie od ingerencji Magisterium. ${ }^{54}$ Bóg postrzegany jest jako nieprzyjaciel ludzkiej wolności, jako władca i tyran, konkurent człowieka, podczas gdy to On właśnie stworzył wolność i jest jej najszczerszym przyjacielem. ${ }^{55}$ Bóg nie jest wielkim Nieznanym, którego ledwo jesteśmy

${ }_{51}$ Por. J a n P a w e 1 II, Kościót jest miejscem, w którym sumienie ludzkie wzrasta i dojrzewa, nr 3.

52 Por. J. R a t z i nge r, Bóg jest blisko nas. Eucharystia: centrum życia, s. 120; t e n ż e, Prawda, wartości, władza, s. 25-26.

53 Por. te n ż e, Bóg jest blisko nas. Eucharystia: centrum życia, s. 120; R. K a$\mathrm{m}$ i ń s k i, Duszpasterstwo w społeczeństwie pluralistycznym, s. 37.

54 Por. L. M e li n a, Sumienie - wolność - Magisterium, s. 109.

55 Por. J. R a t z i n g e r, Jezus Chrystus dzisiaj, w: B e n e d y k t X V I, J. K ró1 i k o w s k i, Z Chrystusem w historii. Rozważania chrystologiczne, Kraków 1999, s. 25; J a n P aweł II, „Tak” dla Kościoła, nr 6. 
w stanie sobie wyobrazić. Nie musimy, jak poganie, obawiać się, że być może jest kapryśny, okrutny, zbyt odległy albo zbyt wielki, by słuchać człowieka. ${ }^{56}$ „Chrześcijaństwo nie jest religią «czystego» Absolutu ani też «samotnego» Absolutu. Bóg, w którego wierzymy jest Bogiem Żywym... a także jest Bogiem historii". ${ }^{57}$ Oznacza to, że ten Bóg ukazuje się nam, spogląda z wieczności na nasze czasy i nawiązuje z nami kontakt.

Dlatego jedynie we wzajemnej relacji z Bogiem życie ludzkie staje się życiem autentycznym. Bez Niego poniża ono siebie i ulega zniszczeniu. ${ }^{58}$ Tego rodzaju deformacja Ewangelii prowadzi jedynie do frustracji albo do cynizmu. Chrześcijańska nowina nie jest zbiorem abstrakcyjnych tez teologicznych, lecz spotkaniem Boga z naszym światem, z rzeczywistością naszych domów i naszego życia, a Jego przykazania mają tylko jeden cel: pomagać ludziom w unikaniu najgorszej i najbardziej haniebnej niewoli, jaką jest niewola niemoralności, i sprzyjać szerzeniu się wolności. Każda norma moralna jest więc tylko wyrazem wymogów prawdy miłości. ${ }^{59}$

Eklezjalność moralności chrześcijańskiej nie oznacza jakiegoś niedowartościowania sumienia, ale wskazuje na konieczność jego eklezjalnej interpretacji, albowiem nie ma żadnej naczelnej i niewzruszonej podstawy bezwarunkowego charakteru prawa i obowiązku moralnego oprócz Boga. ${ }^{60}$ Uczniowie Jezusa Chrystusa, zobowiązani do postępowania zgodnie z własnym sumieniem na drodze poszukiwania prawdy, wiedzą, że nie należy ufać jedynie własnej zdolności moralnego osądu. ${ }^{61}$ Nie jest ona czymś zewnętrznie narzuconym sumieniu, lecz stanowi jego wewnętrzny wymiar, co więcej, warunek

${ }_{56}$ Por. J. R a t z i n g e r, Bógjest blisko nas. Eucharystia: centrum życia, s. 118.

57 A. F r o s s a r d, ,Nie lękajcie się”. Rozmowy z Janem Pawłem II, s. 190.

58 Por. J. R a t z i n g e r, Bóg jest blisko nas. Eucharystia: centrum życia, s. 9; t e n ż e, Jezus Chrystus dzisiaj, s. 26.

59 Por. J a n P a w e ł II, ,Tak” dla Kościoła, nr 6; t e n ż e, Wolność jest łaska i nakazem, nr 3.

${ }^{60}$ Por. J. M a r it a i n, Moralne i duchowe wartości w wychowaniu, s. 132.

61 Por. J a n P a w e 1 II, Orędzie na Światowy Dzień Pokoju 1991, w: Orędzia Jana Pawła II, Kraków 1998, nr 8. 
jego prawidłowego działania. Prawo staje się ciężarem dopiero w tym momencie, gdy nie jest przeżywane od wewnątrz, lecz jest rozłożone na wiele zewnętrznych i powierzchownych zobowiązań. ${ }^{62}$ „Bóg nie tylko wpisał prawo naturalne w każde ludzkie serce, (...) lecz objawił także swe własne prawo w Piśmie Świętym". ${ }^{63} \mathrm{~W}$ słowie Bożym została nam objawiona wola Boża i sens naszej własnej istoty. Katolicy przekonani są o tym, że Pismo Święte przekazane zostało Kościołowi oraz że jednostka może je poznać i zrozumieć w sposób poprawny wyłącznie dzięki żywej łączności z Kościołem. ${ }^{64}$

Dzięki Duchowi Świętemu Kościół jest miejscem i źródłem wszelkiego poznania moralnego. Duch Pański, który oświeca od wewnątrz sumienie chrześcijańskie, zapewnia mu także wewnętrzny przybytek i weryfikację. ${ }^{65}$ Prawda objawiona przez Boga została oddana w depozyt Kościołowi. W ostatecznym więc rozrachunku Kościół jest tą atmosferą i tym porządkiem, w którym indywidualne oko widzi całkowicie swój przedmiot: objawienie. ${ }^{66}$

Najbardziej autentycznym i wiernym interpretatorem Pisma Świętego jest Urząd Nauczycielski Kościoła. Dlatego w celu prawidłowego ukształtowania sumienia należy słuchać nauczania Kościoła, podawanego wiernym w różnych formach: katechizacji dzieci, młodzieży i dorosłych, głoszenia kazań i homilii, różnych prelekcji i konferencji religijnych, nauk stanowych rekolekcyjnych i misyjnych, konferencji przedmałżeńskich oraz dla małżonków i rodziców itp. ${ }^{67}$ Nie chodzi jednakże tylko o to, by korzystać z duchowych usług Kościoła, usług nieomylnie skutecznych, bo zapewniających realny dostęp do

${ }^{62}$ Por. J. R a t z i ng e r, Bógjest blisko nas. Eucharystia: centrum życia, s. 121.

${ }_{63} \mathrm{~J}$ a n $\mathrm{P}$ a w eł II, Orędzie na Światowy Dzień Pokoju 1991, nr 8.

${ }^{64}$ Por. J. R a $\mathrm{z}$ i ng e r, Bóg jest blisko nas. Eucharystia: centrum życia, s. 120; R. G u a r d i n i, Pismo Święte i nauka wiary. Poznanie duchowe, które otrzymuje się $w$ darze, s. 62.

${ }^{65}$ Por. L. M e 1 i n a, Sumienie - wolność-Magisterium, s. 112.

${ }^{66}$ Por. R. G u a r d i n i, Pismo Święte i nauka wiary. Poznanie duchowe, które otrzymuje się $w$ darze, s. 66.

${ }_{67}$ Por. M. W o 1 i c k i, Dojrzała osobowość, dojrzałe sumienie, Wrocław 2000, s. 146. 
mocy i obecności Chrystusa Pana. Każdy wierzący w Chrystusa winien dążyć do pełnego włączenia się w Kościół, by stać się jego nierozerwalną cząstką. ${ }^{68}$

W przypadku wątpliwości sumienia Kościół ułatwia zdobycie pewności, stanowiącej konieczny warunek normatywnej roli sumienia w życiu moralnym. Działanie Kościoła chroni ponadto jednostkę, co do interpretacji Pisma, od wpadnięcia w pułapkę modnych nurtów kulturowych i naukowych dominujących w określonym czasie. ${ }^{69}$ Współcześnie wiele rozmaitych poglądów na temat sztuki, polityki, moralności, wypowiada się, niestety, nie dlatego, że tak naprawdę się myśli, ale dlatego, że dzisiaj tak się myśli i mówi. Problemem naszych czasów jest właśnie to, że myślimy tylko w kategoriach funkcjonalnych, że człowieka klasyfikuje się według jego wartości funkcjonalnej. Księga Ewangelii, tradycja kościelna i nauczanie doktrynalne pasterzy stanowią pewną pomoc dla chrześcijańskiego sumienia. Wszystkie te rodzaje działalności nauczycielskiej Kościoła zmierzają do ukształtowania prawidłowo funkcjonującego sumienia wiernych. Szczególnie w czasach osłabienia, zafałszowania lub zaniku wartości, Kościół pełni zobowiązującą funkcję adwokata, obrońcy sumień, których oczyszczenie jest warunkiem każdej reformy społecznej i poprawy ludzkich spraw. ${ }^{70}$ Cóż to jednak oznacza w praktyce? Oznacza tyle mianowicie, że Kościół, będąc sumieniem społeczeństwa, tylko wówczas jest miejscem wyzwolenia i wolności, gdy pozostaje głosem tych, którzy nie mają głosu, gdy staje w obronie biednych i uciśnionych. ${ }^{71}$

${ }^{68}$ Por. J. S a lij, Po co nam Kościót? s. 13.

${ }^{69}$ Por. R. G u a r d i n i, Pismo Święte i nauka wiary. Poznanie duchowe, które otrzymuje się $w$ darze, s. 66.

70 Por. J. R a t z i nge r, Bóg jest blisko nas. Eucharystia: centrum życia, s. 99, 112.

71 Por. J. K r u c i n a, Sumienie społeczeństwa, Wrocław 1995, s. 203. Konieczne jest tu drobne sprostowanie co do sformułowania „sumienie społeczeństwa”. Sumienie przypisać można tylko konkretnemu człowiekowi, a nie strukturom czy społeczeństwu; zob. I. M r o c z k ow s k i, Wyzwania przed ludźmi sumienia 
Jak zatem wynika z powyższych rozważań Kościół spełnia istotną rolę w kształtowaniu treści i przeznaczenia nadprzyrodzonego człowieka. Dzieje się tak dlatego, że Kościół ma bogate doświadczenie w sprawach ludzkich i bynajmniej nie zamierza poprzestać w tym zakresie jedynie na osiągnięciach psychologii i nauk jej pokrewnych. ${ }^{72}$ Zespolenie postawy nauczycielskiej i formacyjnej wspólnoty Kościoła powinno być obecnie w każdym jego wymiarze: w strukturach i działaniu, zarówno w historii, jak i wszystkich drogach świata i człowieka. Należy jednocześnie podkreślić, że integralna formacja chrześcijańska nie ogranicza się do wybranego środowiska czy uprzywilejowanej grupy osób, ale jest otwarta na wszystkich ochrzczonych. Dlatego Kościół nie koncentruje uwagi tylko na jednym środowisku, ale ciągle zabiega o to, by miejscem przekazu wiary były jednocześnie parafia, szkoła i rodzina. ${ }^{73}$

Aby jednak Kościół mógł stać się dziś wiarygodnym świadkiem i wychowawcą ludzkich sumień, jego członkowie winni być ludźmi prawego sumienia, przez które pozwalają się Bogu prowadzić. Dlatego w Kościele konieczna jest przede wszystkim permanentna formacja osób odpowiedzialnych za wychowanie i przekaz wiary innym członkom wspólnoty. ${ }^{74}$ „W Kościele Jezusa Chrystusa nikt nie powinien czuć się zwolniony od przyjmowania katechizacji. Dotyczy to nawet tych, którzy są powołani do zadań pasterzy i katechizujących: tym lepiej będą oni spełniać to zadanie, kiedy z pokorą zajmą miejsce w szkole Kościoła, wielkiego katechety i równocześnie wielkiego katechizowanego". ${ }^{75}$ Formacja osób odpowiedzialnych za przekaz wiary innym powinna więc znaleźć się wśród zadań priorytetowych diecezji i wejść do programów duszpasterskich tak,

w Polsce, w: J. N a gó r n y, A. D e r d z i u k (red.), Człowiek, sumienie, wartości. Materiały z sympozjum KUL, 2-3 XII 1996 r., Lublin 1997, s. 128.

72 Por. S. O le j n i k, Teologia moralna fundamentalna, s. 264; zob. także: P a w e 1 VI, Populorum progressio, nr 13.

73 Por. J. K o c h e 1, Katecheza ewangelizacyjna w nauczaniu pastoralnym Carlo Maria Kard. Martiniego, Opole 1999, s. 64.

74 Por. tamize, s. 61.

75 CT nr 45. 
by ku niej zmierzały wszystkie wysiłki wspólnoty. Formacja prawego sumienia wiernych, poczynając od dzieci i młodzieży, musi być stałą troską Kościoła. Kościół katolicki jest bowiem najpoważniejszym bojownikiem o ludzką wolność. ${ }^{76}$

\section{Wychowawcza funkcja parafii - zadanie do ponownego odczytania}

W kontakcie z konkretnym katolikiem Kościół realizuje się przede wszystkim przez parafię, która jest środowiskiem wychowawczym, gdyż w jej rozlicznych funkcjach - zarówno podstawowych jak i uzupełniających - z łatwością znajduje się działania wychowawcze. Spektakularnym obszarem wychowawczej pracy parafii jest oczywiście katecheza. ${ }^{77}$

W adhortacji apostolskiej Catechesi tradendae parafia została nazwana krzewicielką i inspiratorką katechezy. ${ }^{78} \mathrm{~W}$ wizji integralnego wychowania młodego człowieka parafia pełni ważną rolę w procesie rozwoju wiary oraz ,jest [ona] (...) najbardziej znaczącym miejscem, w którym formuje się i żyje wspólnota chrześcijańska". ${ }^{79}$ Dlatego katechizacja w szkole domaga się uzupełnienia o wymiar parafialny duszpasterstwa dzieci i młodzieży. ${ }^{80}$ Parafia, przedstawiając

76 Por. J. R. N e u h a u s, Biznes i Ewangelia, Poznań 1993, s. 174. Zob. także: ChL nr 57; J a n P a w e 1 II, Odnowa człowieka i społeczeństwa dokonuje się za sprawa odnowy sumień, nr 2.

77 Por. A. P o t o c k i, Wychowanie religijne w polskich przemianach, Warszawa 2007, s. 18-19.

78 Por. CT nr 67

79 DOK nr 257.

${ }^{80} \mathrm{~J}$ a n P a w e $\nmid$ II, $W$ trosce o wielki i ofiarny czyn nowej ewangelizacji. Przemówienie do drugiej grupy biskupów polskich przybylych z wizyta „Ad limina”, 02.02.1998 r., L’Osservatore Romano (wyd. pol.) 3/1998; 5/1998. Słowa te (wypowiedziane już 12 I 1993 r.) papież powtórzył do biskupów polskich przybyłych do Rzymu z wizytą Ad limina Apostolorum w 1998 r. Świadczą one niewątpliwie o wielkiej trosce Ojca Świętego o katechizację parafialną, a jednocześnie wskazują na niedostateczne jeszcze zrealizowanie postulatów zakomunikowanych podczas poprzedniej wizyty duszpasterskiej biskupów polskich w Rzymie. 
w pewien sposób widzialny Kościół ustanowiony na całej ziemi $\mathrm{i}$ będąc niejako jego ostatecznym umiejscowieniem, z istoty swojej jest powołana do realizowania w sobie pełni życia chrześcijańskiego. ${ }^{81}$

Formacja chrześcijańska zaś łączy się ściśle z formacją moralną. Moralny zaś wymiar dojrzałości osobowej oznacza prawidłowo ukształtowane sumienie, inspirujące człowieka nie tylko do wypełniania obowiązków i dążenia do osiągnięcia prawdy i dobra, ale przede wszystkim przynaglające do czynnej miłości Boga i bliźniego. ${ }^{82}$ Parafia jest bowiem powołana do tego, by troszczyć się o tworzenie duchowej więzi człowieka z Bogiem, a jednocześnie o pogłębienie więzi zrozumienia i miłości między ludźmi. ${ }^{83}$ Osiągnięcie tego stanu jest możliwe w wyniku wszechstronnej i systematycznej formacji. To istotne zadanie bezpośredniej i osobistej formacji katolików świeckich przypada właśnie parafii, która powinna być pierwszoplanowym miejscem katechizacji. Wyraźnie na to wskazuje eklezjologiczne znaczenie sakramentów. ${ }^{84}$ Katechizacja dzieci i młodzieży należy bowiem do fundamentalnych zadań całego duszpasterstwa i powinna towarzyszyć jej, w sposób nieodzowny, katecheza dorosłych, a szczególnie katecheza środowiska rodzinnego. ${ }^{85} \mathrm{~W}$ zasadzie kolejność powinna być odwrotna. Dokument La catechesi degli adulti nella comunita cristiana, wydany przez Międzynarodową Radę do spraw Katechezy, wyraźnie wskazuje na pierwsze i najważniejsze miejsce katechezy dorosłych w życiu parafialnym. Warunkuje ona bowiem nie tylko tworzenie dojrzałych wspólnot chrześcijańskich,

${ }^{81}$ Por. KL nr 42; ChL nr 26; F. W o r o n o w s k i, Potrzeba i możliwości wprowadzenia elementów ewangelizacji do katechezy parafialnej, w: S. D z i e k o ń s k i (red.), Katecheza ewangelizacyjna w rodzinie, parafii, szkole, Warszawa 2002, s. 101.

82 Por. M. S ę d e k, Drogi dojrzałości, Krościenko 2002, s. 47.

${ }^{83}$ Por. J a n P a w e 1 II, $W$ trosce o wielki i of iarny czyn nowej ewangelizacji, nr 3.

${ }^{84}$ Por. ChL 61; CT nr 67; S. S t u ł k o w s k i, Wiary można uczyć się tam, gdzie się doświadcza. Parafia miejscem i nośnikiem katechezy, Teologia praktyczna t. $2 / 2001$, s. 129.

85 Por. DOK nr 258. 
ale i skuteczność katechezy dzieci i młodzieży, z których formami powinna być ściśle zintegrowana. Dlatego wspólnota parafialna, jako zajmująca szczególne miejsce, powinna pozostać krzewicielką i inspiratorką katechezy. ${ }^{86}$

\section{Katecheza parafialna narzędziem ewangelizacji}

Współczesne uwarunkowania życia sprawiają, że katecheza parafialna powinna mieć charakter ewangelizacyjny. Wyraźnie wskazują na to normy zawarte w Dyrektorium ogólnym o katechizacji. ${ }^{87}$ Jej intencją powinna być ewangelizacja chrześcijan rozumiana jako towarzyszenie człowiekowi w różnych momentach jego życia w celu umożliwienia mu głębszego zrozumienia Dobrej Nowiny i prowadzenia życia nią inspirowanego. ${ }^{88}$ Zadaniem katechezy ewangelizacyjnej powinno być ponadto przypominanie podstawowych elementów wiary; inspirowanie w rzeczywistym procesie nawrócenia; pogłębienie prawdy i wartości orędzia chrześcijańskiego wobec rozmaitych zastrzeżeń, jakie wysuwa świat współczesny. ${ }^{89}$

Katecheza, obok takich form służby sumieniu jak: duszpasterstwo młodzieży, życie sakramentalne i modlitewne, a także kierownictwo duchowe, winna pomagać młodemu człowiekowi w dojrzewaniu do odpowiedzialnego dokonywania życiowych wyborów, do wierności i stałości. ${ }^{90}$ Katecheza nosząca znamiona katechezy ewangelizacyjnej

86 Por. K. M i s i a s z k, Katecheza parafialna-rzeczywistość i oczekiwania, w: Komunikacja wiary w trzecim tysiącleciu, Episteme 6/2000, s. 71; zob. także: DOK nr 72.

87 Por. S. D z i e k oń s k i Ewangelizacja w podstawowych środowiskach katechetycznych, w: te n że (red.), Ewangelizować czy katechizować? Warszawa 2002, s. 224; P. To m a s i k, Nauczanie religii w publicznym liceum ogólnokształcacym wobec założeń programowych polskiej szkoły, Warszawa 1998, s. 172.

88 Por. S. S t u ł k o w s k i, Wiary można uczyć się tam, gdzie się doświadcza, Parafia miejscem i nośnikiem katechezy, s. 129.

89 Por. DOK nr 194.

90 Por. Jan P aw eł II, Odnowa człowieka i społeczeństwa dokonuje się za sprawa odnowy sumień, nr 6. 
ma uprzywilejowane miejsce w parafii. Można nawet powiedzieć odważnie, że według norm zawartych w Dyrektorium ogólnym o katechizacji katecheza $\mathrm{w}$ ramach parafii powinna mieć charakter ewangelizacyjny. Nie wyklucza i nie zastępuje ona jednak innych środowisk i miejsc katechizowania. ${ }^{91}$

Katecheza parafialna, która ma przeobrażać parafię w organiczną wspólnotę komplementarną, musi - wbrew wszelkim słabościom ludzi i różnorodnym trudnościom - formować osobiste i społeczne życie swych członków tak, by stawali się świadkami miłości. ${ }^{92}$ Jest to możliwe, ponieważ katecheza, jako integralna część procesu ewangelizacji oraz służąca wtajemniczeniu chrześcijańskiemu, jest organiczną i systematyczną formacją wiary. Ta formacja wewnętrzna, prowadzona konsekwentnie i z umiejętnością, sprawi, że będą oni mogli się poczuć rzeczywistymi podmiotami w życiu Kościoła i przejąć na swe barki należną im odpowiedzialność w Kościele i w społeczeństwie. ${ }^{93}$ Przez współudział bowiem rodzi się identyfikacja. Jeśli człowiek nie widzi w parafii zadań dla siebie, nie czuje się odpowiedzialny za to, co się w niej dzieje. Tylko ten, kto współpracuje, przeżywa w pełni wspólnotę. Do posługi katechetycznej powołani są bowiem wszyscy członkowie wspólnoty parafialnej. Troską tą objęci są wszyscy, a szczególnie dzieci i młodzież, których nie można pozostawić bez pomocy i bez kierownictwa na rozdrożach życia i w obliczu trudnych wyborów. ${ }^{94}$ Nikogo nie możemy uważać za straconego, bo Chrystus umarł za wszystkich, otwierając każdemu

91 Por. M. Z a ją c, Praktyka katechizacji, w: R. K a m i ń s k i (red.), Teologia pastoralna, t. 2: Teologia pastoralna szczegółowa, Lublin 2002, s. 209; por. DOK 258. Zob. J. To m c z a k, Katecheza młodzieży w nauczaniu Jana Pawła II, w: R. M u r a w s k i (red.), Teoretyczne założenia katechezy młodzieżowej, Warszawa 1989, s. 140; CT nr 67.

92 Por. F. W o r o n o w s k i, Potrzeba i możliwości wprowadzenia elementów ewangelizacji do katechezy parafialnej, s. 108.

${ }_{93}$ Por. J a n P a w e $\nmid$ II, $W$ trosce $o$ wielki $i$ ofiarny czyn nowej ewangelizacji, nr 3; zob. DOK nr 67.

94 Por. K. R y c z a n, Miejsce i rola młodzieży w parafii, Seminare 1986, s. 59. 
drogę do życia wiecznego. ${ }^{95}$ Opatrzność Boża daje szansę spełnienia się każdemu, nawet temu, kto po ludzku stracił wszelkie szanse. Na szczególne trudności w zachowaniu wiary narażona jest młodzież szkół ponadpodstawowych i wyższych. ${ }^{96}$

\section{Wspólnota parafialna miejscem naturalnego rozwoju wiary}

Metodą formacji sumienia jest otwarcie się na wspólnotę, która swój najbardziej bezpośredni i widzialny wyraz znajduje w życiu parafii. W niej bowiem chrześcijanie doświadczają swej zbudowanej na wierze wspólnoty, która jest ,początkiem, miejscem i celem katechezy". ${ }^{97}$ Parafia spełnia warunki niezbędne do życia wspólnoty parafialnej także z tego powodu, że jest miejscem, w którym wszyscy wierni mogą się gromadzić na niedzielną celebrację Eucharystii. W związku z tym stanowi środowisko, w którym orędzie Chrystusowe jest głoszone i przyjmowane. Wspólnota chrześcijańska przyjmuje bowiem tych, którzy pragną poznać Jezusa i zaangażować się w nowe życie. ${ }^{98}$

Zadaniem parafii jest w przede wszystkim budzenie wiary (rodzenie wiary) potrzebnej do zbawienia i jej komunikowanie. ${ }^{99}$ Ono wynika w głównie z tego, że parafia jest wspólnotą eucharystyczną, a więc wspólnotą wiary i wspólnotą organiczną. ${ }^{100}$ Dlatego II Synod Plenarny Kościoła w Polsce wskazuje - jako jedno z aktualnych zadań stojących przed duszpasterstwem - zbudowanie katechezy

95 J a n P awe $\nmid$ II, Przesłanie do Biskupów z Konferencji Episkopatu Polski z 08061997 r., w: Program dla Kościoła w Polsce. Wizyta „, Ad limina Apostolorum”, Kraków 1998, nr 2.

96 Por. M. R u s i e c k i, Istota i sens samowychowania, Obecni w religii, społeczeństwie, kulturze 3/2002, s. 28.

97 DOK nr 254; por. ChL nr 26.

98 Por. KKK nr 2179; K. M i s i s z e k, Katecheza parafialna-rzeczywistość i oczekiwania, s. 69.

99 Por. S. D z i e k oń s k i Ewangelizacja w podstawowych środowiskach katechetycznych, s. 222; K. R y c z a n, Miejsce i rola młodzieży w parafii, s. 59.

${ }^{100}$ Por. ChL nr 26. 
parafialnej, która umożliwiałaby systematyczny przekaz wiary w środowisku, gdzie jest ona żywa. ${ }^{101}$ Parafia może stanowić zatem punkt odniesienia dla osób poszukujących żywego Kościoła, miejsca autentycznej modlitwy i dialogu, życzliwości, środowiska przyciągającego autentyzmem życia. Wspólnota wiary sprawia, że katecheza daje nie tylko możliwość przepowiadania wiary, ale jednocześnie pozwala jej doświadczyć wtedy, gdy się ją świętuje (liturgia) i praktykuje (diakonia). Dzięki tym działaniom spotkanie z Kościołem w parafii staje się rzeczywiste i bezpośrednie, ponieważ tutaj życie codzienne wiernych spotyka się z realną obecnością odkupienia. Wszak zadaniem Kościoła jest pośrednictwo w przekazywaniu wszystkim ludziom, a przede wszystkim swoim członkom, osobowej relacji z Odkupicielem, Jezusem Chrystusem. ${ }^{102}$

Prowadzenie parafii, jako wspólnoty, do świętości wymaga korzystania ze wszystkich dobrodziejstw wiary, tj. z pełni sakramentów i innych środków zbawczych będących w dyspozycji Kościoła, w szczególności zaś rozbudzania w niej modlitwy i uczestnictwa w Eucharystii (tj. wychowania swoich członków do osobistego i liturgicznego dialogu z Bogiem), korzystania z sakramentu pojednania, słuchania słowa Bożego, przybliżania znaczenia kościelnej komunii i misyjnej odpowiedzialności oraz „praktykowania miłości Pana w dobrych i braterskich uczynkach". Przez wszystkie te czynniki Kościół realizuje swą diakonijną posługę, kształtując tym samym wrażliwość moralną i etyczną. ${ }^{103}$

W nauczaniu katechetyczno-homiletycznym należy jednocześnie podkreślać, że chrześcijanin nie powinien pojmować praw i zasad moralnych jako sumy nieosobowych wskazań, nakazów czy zakazów,

${ }^{101}$ Por. II Polski Sy nod Ple n a rny, Potrzeby i zadania nowej ewangelizacji na przełomie II i III Tysiąclecia Chrześcijaństwa, s. 48.

102 Por. R. K a m i ń s k i, Urzeczywistnianie się Kościoła dzisiaj, w: t e n ż e (red.), Teologia pastoralna, t. 1: Teologia pastoralna fundamentalna, s. 158; P. J. C o r d e s, Znaki nadziei. Ruchy i nowe rzeczywistości w życiu Kościoła w wigilięjubileuszu, Częstochowa 1998, s. 182.

${ }^{103}$ KKK nr 2179; por. ChL nr 61; F. W o r o n ow s k i, Potrzeba i możliwości wprowadzenia elementów ewangelizacji do katechezy parafialnej, s. 107. 
lecz winien odznaczać się tęsknotą za pełnią przekraczającą legalizm nakazów i zakazów. ${ }^{104}$ Mniej lub bardziej ukryty moralizm jest bowiem jedną z podstawowych przeszkód uniemożliwiających człowiekowi autentyczne przyjęcie Kazania na Górze. ${ }^{105}$

Poddanie się w ten sposób przebiegającej formacji jest niezbędne, by parafia przechodziła ze spłyconego życia religijnego w społeczność nowej „ery ludzi świętych”. Cała wspólnota jest powołana do tego, by głosić Ewangelię. Formacja religijna tego, kto przyjął sakramenty wtajemniczenia i wszedł do wspólnoty Kościoła, powinna przebiegać dalej, by zapewnić mu formację apostolską, do której jest zobowiązany jako chrześcijanin. Do katechezy parafialnej należy bowiem wszystko, co w ciągu życia chrześcijańskiego człowieka przyczynić się może do rozwoju jego refleksji nad świadomością własnej wiary oraz do odpowiadającego jej stylu życia. ${ }^{106}$

Formacja apostolska chrześcijan powinna obejmować również katechezę naświetlającą życie zawodowe chrześcijan. Ważne jest przy tym także, by zatroszczyć się w parafii o konkretny, dostosowany do poszczególnych kategorii młodzieży, rodzaj katechezy, np. akademickiej, licealnej, pracowniczej itp. ${ }^{107}$ Katecheza dla poszczególnych grup zawodowych staje się dziś koniecznością. Bardzo istotne wydaje się rozeznanie sytuacji, w jakiej żyją dzieci i młodzież, by do tego dostosować odpowiednią koncepcję działania. Skuteczna katecheza zakłada potrzebę dostosowania przekazu Ewangelii do grup jednorodnych reprezentujących zbliżony poziom intelektualny, mający podobny zakres doświadczeń życiowych i zawodowych. Bez

104 Por. J. O r z e s z y n a, Kształtowanie sumienia podstawowym obowiąziem chrześcijanina, Sosnowieckie Studia Teologiczne t. 3/1997, s. 70; zob. VS nr 16.

105 Tym, co pobudza i ukierunkowuje stały proces formacji człowieka, jest spotkanie z Chrystusem. Dzięki interakcji z Bogiem w Jezusie Chrystusie chrześcijanin stara się postępować według etyki ewangelicznej żywo kształtowanej w jego wnętrzu; por. K. P ó ł t o r a k, Pedagogika pastoralna. Nowe inspiracje duszpasterskie, s. $69-70$.

${ }^{106}$ Por. S. S t u 1 k o w s k i, Wiary można uczyć się tam, gdzie się jej doświadcza, s. 128.

${ }^{107}$ Por. K. R y c z a n, Miejsce i rola młodzieży w parafii, s. 59. 
budzenia utrwalania i pogłębiania świadomości eklezjalnej, życie religijne parafii spłyca się, występuje osłabienie wrażliwości sumień, lekceważenia grzechu, brak rozumienia miłości, potrzeby świętości, komunii. ${ }^{108}$ „We współczesnym świecie nie można żyć wiarą bez jej intelektualnego pogłębienia". ${ }^{109} \mathrm{~W}$ przeciwnym razie, jeśli zabraknie poważnego studium nauki chrześcijańskiej, grupy, w których zjawisko to wystąpi, będą oszukiwać i swoich członków, i Kościół. ${ }^{110}$

Parafia pełni funkcję środowiska, w którym chrześcijanie wzajemnie uczą się od siebie wiary przez wypełnianą funkcje wtajemniczenia chrześcijańskiego. ${ }^{111}$ Procesy te odbywają się na drodze uczenia go modlitwy oraz wprowadzania w rozumienie i udział w liturgii oraz życiu sakramentalnym Kościoła ${ }^{112}$. Przez parafie przekazywane są treści religijne, które mogą okazać się znaczące do pełnego rozwoju człowieka. Otwieranie wychowanka na Transcendencję, na sacrum, pomaga w przybliżaniu mu świata przeżyć i wartości interpretowanych w świetle wiary. ${ }^{113}$

Wspieranie działań pedagogicznych przez parafię dokonuje się na drodze wyjaśniania oraz ukazywania wartości życia wspólnotowego. Sprzyja temu tworzenie grup, w których można dzielić się własnymi doświadczeniami (nie tylko doświadczeniami wiary), dyskutować nad aktualnymi zadaniami wynikającymi z życia chrześcijańskiego. W ten sposób ułatwia się wychowankom proces internalizacji pojęć i wartości religijnych. Osoby żyjące w środowisku, w którym mają oparcie w postawie wiary praktykowanej przez innych na co dzień,

${ }^{108}$ Por. M. Z a j ą c, Praktyka katechizacji, s. 209; F. W o r o n o w s k i, Potrzeba i możliwości wprowadzenia elementów ewangelizacji do katechezy parafialnej, s. 106.

${ }^{109} \mathrm{PDK}$ nr 53.

110 Por. CT nr 47.

111 Por. W. K u b i k, Zarys dydaktyki katechetycznej, Kraków 1992, s. 77-78; P. To m a s i k, Charakterystyka Dyrektorium ogólnego o katechizacji, w: Katecheza Kościoła w świetle Dyrektorium ogólnego o katechizacji, Kraków 1999, s. 62.

112 Por. PPK, s. 25.32-33

113 Por. Z. M a re k, Rozwój teorii religijnego wychowania dziecka w wieku przedszkolnym w Polsce w latach 1945-1990, Kraków 1994, s. 94-95. 
mają szanse przejmowania i praktykowania określonych postaw oraz uznania je za własne. ${ }^{114}$

\section{Wspólnota - środowisko dojrzewania religijnego człowieka}

Trudności i problemy wieku młodzieńczego domagają się grupowego ich przezwyciężania. Człowiek, by być pewny, że nie oszukuje siebie, powinien we wspólnocie moralnej konfrontować z innymi to, co uważa za dobre i słuszne. Wszak w grupie łatwiej żyć i postępować po chrześcijańsku. ${ }^{115}$ „Człowiek z głębi swej natury jest istotą społeczną, toteż bez stosunków z innymi ludźmi nie może ani żyć, ani rozwijać swoich uzdolnień". ${ }^{116}$ Poza tym młodzież w sytuacji zagubienia i niepewności potrzebuje oparcia w osobach, które nie byłyby zagrożeniem dla jej autonomii. ${ }^{117}$ Człowiek współczesny bowiem jest bardzo uczulony na szacunek dla wolności i szybko zniechęci się do rozmówcy, który jest natrętem.

Program określony przez Jana Pawła II w liście apostolskim Novo millennio ineunte wymaga formowania świętości i komunii miłości, czyli ewangelicznego autentyzmu - pełni życia chrześcijańskiego, wyjścia z religijności spłyconej i zawężonej. Temu m.in. służy katecheza, która jest wychowaniem do poznania i życia wiarą w taki sposób, by cały człowiek w swoich najgłębszych doświadczeniach, czuł się ożywiony przez słowo Boże. ${ }^{118} \mathrm{~W}$ tym celu parafia pomaga nie tylko przekazywać prawdy - wprowadzenie w życie chrześcijańskie musi być bowiem czymś więcej niż tylko suchym przekazaniem wiedzy - ale też stwarza przestrzeń do realizowania miłości. ${ }^{119}$ Młodzi

114 Por. P. To m a s i k, Charakterystyka Dyrektorium ogólnego o katechizacji, s. 63.

115 Por. K. R y c z a n, Miejsce i rola młodzieży w parafii, s. 56.

116 KDK nr 12.

117 Por. J. S ł o m iń s k a, Mechanizmy i funkcje grup młodzieżowych, w: R. M ur a w s k i (red.), Teoretyczne założenia katechezy młodzieżowej, s. 50.

118 Por. F. W o r o n o w s k i, Potrzeba i możliwości wprowadzenia elementów ewangelizacji do katechezy parafialnej, s. 103; zob. DOK nr 67.

119 Por. CT nr 18, 23. 
uczestniczący w spotkaniach parafialnych mogą w najbliższym otoczeniu doświadczyć życia wspólnoty, której naczelną zasadą jest miłość chrześcijańska. Dzięki niej człowiek może zrozumieć siebie oraz zrealizować swe ludzkie powołanie przez ofiarną i wielkoduszną służbę drugim. Katechizowanie oznacza nie tylko przedstawianie chrześcijaństwa jako systemu ideowego (Kościół jest czymś więcej niż tylko reprezentantem jakiegoś określonego kodeksu zachowania), lecz jako osobę Jezusa Chrystusa, który zna łaskę, pozwalającą nam postrzegać siebie i innych oczyma Jezusa. Dlatego oderwanie radykalizmu Kazania na Górze od Chrystusowej łaski prowadzi do swoistej ideologizacji Ewangelii. W tym zadaniu szczególnie powinna odnajdywać się parafia jako „miejsce” zjednoczenia wiernych a zarazem „znak i narzędzie" powołania wszystkich ludzi do życia w komunii. ${ }^{120}$

Niektórzy może zbyt pochopnie uznali, że parafie są przestarzałe, że nawet znikają, a na ich miejsce powinno się tworzyć małe dogodniejsze i sprawniejsze wspólnoty. ${ }^{121} \mathrm{~W}$ Catechesi tradendae papież odrzuca opinię, jakoby parafia zatraciła już swą żywotność w pracy apostolskiej i stała się przestarzała. $\mathrm{Z}$ całą pewnością parafia katolicka pozostanie ciągle jednym z podstawowych środowisk rodzenia się i komunikacji wiary. Poza tym parafia w dalszym ciągu pozostaje miejscem, w którym chrześcijanie, nawet niepraktykujący, złączeni są ścisłymi więzami. Jednak wydaje się wprost niezbędne, by dać parafii stosowniejsze struktury i wlać nowego ducha przez angażowanie wiernych wybitnie uzdolnionych, doświadczonych, odpowiedzialnych i wielkodusznych. ${ }^{122}$ Jej zadaniem, a nawet wyzwaniem, będzie poszukiwanie nowych form przekazu wiary. Istnieje bowiem duża

${ }^{120}$ Por. P. J. C o r d e s, Znaki nadziei. Ruchy i nowe rzeczywistości w życiu Kościoła w wigilie jubileuszu, s. 182. Zob. także: J. R a t z i n g e r, Sól ziemi. Chrześcijaństwo i Kościót katolicki na przełomie tysiącleci. Z kardynałem Josephem Ratzingerem, Benedyktem XVI rozmawia Peter Seewald, Kraków 2011, s. 161; D. K ow a $1 \mathrm{c}$ z y k, Jak kochać złośliwych głupców, czyli o ewangelicznej miłości bliźniego, s. 77; ChL 27.

${ }^{121}$ Por. I. Wrze s iń s k i, Katecheza parafialna, w: R. C z e k a ls k i (red.), Katecheza wobec wyzwań współczesności, Płock 2001, s. 131.

${ }^{122}$ Por. J. To m c z a k, Katecheza młodzieży w nauczaniu Jana Pawła II, s. 140. 
potrzeba ukazywania Kościoła zwróconego ku potrzebom i pragnieniom współczesnego człowieka nie zawsze otwartego na tradycyjne duszpasterstwo. Do współczesnych dzieci i młodzieży należy przyjść $\mathrm{z}$ tą samą Ewangelią, ale głoszoną w sposób nowy i bardziej dostosowany do dzisiejszej mentalności i warunków, w których żyjemy. Jednocześnie ważnym obowiązkiem wspólnoty parafialnej nie przestaje być budowanie wiary ludzi, którzy znajdują dla siebie miejsce w tradycyjnych strukturach parafialnych. ${ }^{123}$

Religijny, światopoglądowy, narodowościowy, kulturowy pluralizm współczesnych, dawniej bardzo jednorodnych społeczeństw, jest faktem. ${ }^{124}$ Taki stan domaga się intensywniejszej refleksji Kościoła nad samym sobą oraz nad jego duszpasterstwem. Dlatego działalność duszpasterska powinna coraz częściej zwracać uwagę na potrzebę uczenia ludzi, jak żyć i wierzyć w społeczeństwie pluralistycznym. Ta sytuacja sprawia, że dąży się do wyzwalania takich inicjatyw, które będą rodziły struktury życia religijnego zdolne ochronić ludzi wierzących przed naporem laicyzacji i dechrystianizacji, które to procesy utrudniają, a nawet wielokrotnie uniemożliwiają zrozumienie racji ewangelizacyjnych czy wychowawczych prowadzonych przez Kościół. ${ }^{125}$ To wymaga poważnego wysiłku skierowanego nie tylko na stworzenie nowych metod dialogu z dziećmi i młodzieżą, ale także na znalezienie właściwych sposobów dotarcia do młodych. Niewątpliwie $\mathrm{z}$ tej potrzeby powstały coraz bardziej żywe ruchy religijne i wspólnoty życia chrześcijańskiego. Sam pluralizm bowiem, pojęty jako akceptowanie wszelkich różnic, nie jest w stanie wywołać impulsów, które mogłyby ludzi ze sobą łączyć. Dopiero ranga prawdy w dialogu, która kształtuje sumienia, nadając kierunek postępowania na rzecz jedności, i przyjęcie jako bazy wspólnej płaszczyzny wartości s. 63.

${ }^{123}$ Por. K. M i s i a s z e k, Katecheza parafialna-rzeczywistość i oczekiwania,

${ }^{124}$ Por. S. W i e 1 g u s, Kościół katolicki dziś, Nasz Dziennik, 16-17 XI 2002, S. 14.

${ }^{125}$ Por. K. M i s i a s z e k, Katecheza parafialna-rzeczywistość i oczekiwania, s. 74 . 
etycznych pozwala dostrzec wartość pluralizmu. Od tego też, jak się tę prawdę w dialogu rozumie, zależy sposób rozumienia pluralizmu. ${ }^{126}$

Parafia w Polsce realizuje swoje zadanie katechizacyjne nie tylko przez katechezę parafialną, ale również przez tworzenie różnych wspólnot, w których odbywa się gruntowna formacja religijna. „Każde (...) z tych zrzeszeń za pomocą sobie właściwych metod umożliwia formację głęboko wszczepioną w doświadczenie życia apostolskiego, a równocześnie daje okazję do integracji, ukonkretnienia i bliższego określenia formacji otrzymanej przez swoich członków od innych osób i wspólnot". ${ }^{127}$ Są one bowiem wszystkie powoływane w tym celu, by ich członkowie realizowali zawsze ten sam cel, którym jest poznanie Jezusa Chrystusa i życie Ewangelią, a więc dzielenie się z sobą wiarą i życiem. ${ }^{128}$ Naśladowanie Chrystusa stanowi bowiem pierwszy i najgłębszy fundament chrześcijańskiej moralności i moralną regułę życia. ${ }^{129}$

Komunikacja wiary w ruchach koncentruje się na doprowadzeniu do odkrycia Boga jako żywego i udzielającego się w miłości oraz do osobowej odpowiedzi na tę miłość przez bezwarunkowe powierzenie się Bogu. ${ }^{130}$ Człowiek może dokonać aktu bezwarunkowej miłości, ponieważ to sam Bóg gwarantuje wieczny sens takiego aktu. Katecheza bowiem, bez względu na miejsce, w jakim jest realizowana, jest przede wszystkim organiczna i podstawową formacją wiary. ${ }^{131}$

II Polski Synod Plenarny, definiując parafię, określa ją jako „wspólnotę wspólnot”. Jest ona dziś postrzegana jako funkcjonalna

${ }^{126}$ Por. S. W i e 1 g u s, Kościół katolicki dziś, s. 14; A. S z o s t e k, Wokót godności, prawdy i miłości, Lublin 1998, s. 288.

${ }^{127}$ DOK nr 261; zob. ChL nr 62.

${ }_{128}$ Por. A. K a l b a r c z y k, Kierowanie grupami parafialnymi, Teologia praktyczna t. 2/2001, s. 88; zob. CT nr 47.

${ }^{129}$ Por. M. S ę d e k, Drogi dojrzałości, s. 51.

${ }^{130}$ Por. W. N o w a c k i, Przekaz wiary w ruchach eklezjalnych - ,elity” czy wspólnota? w: Komunikacja wiary w trzecim tysiacleciu, s. 83.

${ }_{131}$ Por. K. M i s i a s z e k, Katecheza parafialna-rzeczywistość i oczekiwania, s. 67. 
struktura grup i podgrup. ${ }^{132}$ Od razu warto dodać, że nowe ruchy i wspólnoty religijne w niczym nie powinny osłabiać tzw. duszpasterstwa zwyczajnego, związanego z głoszeniem słowa Bożego i szafowaniem sakramentów. Jeśli bowiem chodzi o katechezę, ruchy i stowarzyszenia religijne nie są zwykłą alternatywą dla parafii, gdyż ta jest podstawową wspólnotą wychowującą. ${ }^{133}$ Trudno dziś sobie wyobrazić prawdziwą wspólnotę parafialną bez małych grup.

Współczesność rodzi coraz więcej ludzi poranionych i potrzebujących Chrystusowego przebaczenia i uzdrowienia. Dlatego w obecnej sytuacji potrzebna jest katecheza o pojednaniu i pokucie, o sumieniu i jego kształtowaniu, ponieważ droga do odnowy społeczeństwa prowadzi przez odnowę serca człowieka. Nikt w tym dziele nie zastąpi Chrystusa-Lekarza. W tym procesie nie może zabraknąć świadectwa wewnętrznej przemiany dzieci Kościoła. O ile formacja moralna może dokonywać się znakomicie zarówno w rodzinie, jak i w szkole, to jednak kształtowanie w katechizowanych postaw pokuty i pojednania winno prowadzić do doświadczenia łaski sakramentalnej, a miejscem sprawowania sakramentów jest parafia. ${ }^{134}$

Parafia jest także uprzywilejowanym miejscem katechezy przygotowującej do przyjmowania sakramentów świętych. Oczywiste jest jednak, że katecheza parafialna nie może ograniczać się tylko do przygotowania do sakramentów, ponieważ nie jest ono w stanie zapewnić organiczności procesu katechetycznego. ${ }^{135} \mathrm{O}$ potrzebie katechezy związanej z pokutą mówi posynodalna adhortacja apostolska Reconciliatio et paenitentia. Dokument ten stwierdza, że „najpełniejsza i możliwie adekwatna katecheza o pokucie jest nieodzowna w czasach takich jak nasze, w których dominujące w psychologii

${ }^{132}$ Por. II P o 1 s k i S y n od P 1 e n a r ny, s. 22, przyp. 43; zob. A. K a 1 b a r c z y k, Kierowanie grupami parafialnymi, s. 87.

133 Por. DOK nr 262.

${ }^{134}$ Por. J a n P a w eł II, Polska potrzebuje ludzi ukształtowanych $w$ szkole miłości Chrystusa. Przemówienie do pierwszej grupy biskupów polskich przybyłych z wizyta ,,Ad limina”, 16.01.1998 r., w: Program dla Kościoła w Polsce, nr 5.

135 Por. K. N y c z, Kościót w szkole czy szkoła w Kościele? Pastores 16/2002, s. 21. 
i zachowaniu społecznym poglądy są przeciwieństwem pokuty (...), a współczesnemu człowiekowi przychodzi trudniej niż kiedykolwiek uznanie własnych błędów i decyzja zawrócenia z drogi". ${ }^{136}$ Szczególnego więc znaczenia nabiera dziś apostolstwo miłosierdzia, które służy utwierdzaniu godności człowieka, a także przyczynia się do czynienia świata bardziej ludzkiego. ${ }^{137}$

ks. Marek FILIPCZUK

Słowa kluczowe: wychowanie, Kościół, parafia, sumienie, miłość, prawda, katecheza, ewangelizacja

Keywords: education, Church, parish, conscience, love, truth, catechesis, evangelization

\section{The Educational Function of the Church in Postmodern Times}

\section{Summary}

The educational function of the community is fulfilled through teaching, liturgy and pastoral undertakings. These are the fundamental functions of the Church. If the Good News which the Church proclaims is to remain the Light "which enlightens every man coming into the world", the Church must remain the guarantor of conscience, its guardian, and the defender of the person, thus of humanity itself. The ecclesial character of Christian morality does not take away from conscience per se. It simply points to a need for its ecclesial interpretation since, apart from God, there is no other immutable basis for the absolute character of law and moral obligation.

The parish plays an important role in the integral education of humans and the development of their faith. It is the most significant place in which the Christian community is formed. The parish, therefore, becomes a point of reference for persons seeking a living Church, looking for a place of authentic prayer and dialogue, a friendly community which attracts

\footnotetext{
${ }^{136} \mathrm{ReP}$ nr 26.

137 Por. DiM nr 14; zob. także: Fr a n c i s z e k, Misericordiae vultus, Watykan
} 2015. 
by means of an authentic Christian lifestyle. It is the community of faith that makes catechesis alive in its teaching, celebration (liturgy), as well as practice (diaconate). Thanks to these activities, meeting the Church in the parish becomes real and immediate - it is here that the daily life of the faithful encounters the reality of Salvation. 